\title{
Nevrologisk orden
}

I et foredrag publisert i Tidsskriftet nr. 11/1934 tas det til motmæle mot datidens «gjengse opfatning av nevrologien som den slette prognoses og den håpløse terapis spesielle disiplin». Ragnar Forsberg gjør rede for den «rivende utvikling i løpet av de to siste decennier» på området tumor cerebri. Men først må man få orden på terminologien (Tidsskr Nor Lægeforen 1934; 54: 561 - 73).

\section{Nyere resultater innen den cerebrale diagnostikk.}

Foredrag, holdt i Sarpsborgs og Drammens lægeforeninger.

Av Ragnar Forsberg, reservelæge.

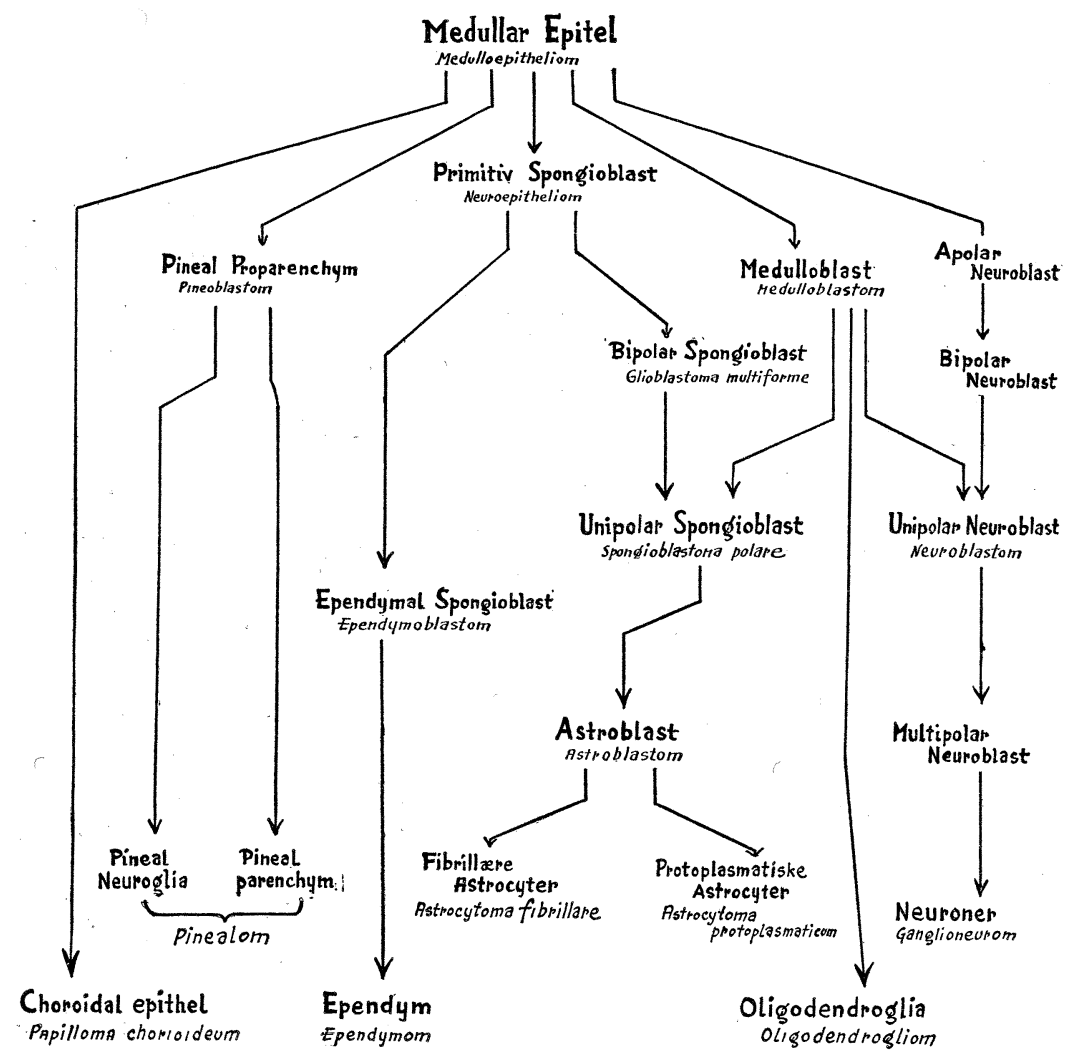

Fig. 2.

I centralnervesystemet finnes der et stort antall forskjellige celleformer. Disse kan som bekjent deles inn i to hovedgrupper: 1. Nevroner. 2. Nevroglia. Disse celler stammer alle fra det føtale medullær-epitel. Fra dette epitel begynner tidlig i fosterlivet forskjellige celleformer å utdifferensiere sig. De viktigste av disse er nevroblastene, som skal utvikle sig til de ferdige nevroner, spongioblastene og medulloblastene. Disse former utvikler sig så videre. Nevroblastene gjennemløper forskjellige stadier og blir til nevroner, se fig 2. Fra medulloblastene utvikles dels celler kjent under navnet oligodendroglia, dels astrocyter. Spongioblastene utvikler sig gjennem flere mellemformer til astrocyter, hvorav der finnes to typer, de fibrillære og de protoplasmatiske, dels til ependymceller o.s.v. De mange navn er egnet til å skape forvirring, jeg nevner dem bare for å lette forståelsen av de betegnelser som de forskjellige gliomformer har fått.
De fleste av disse celleformer var kjent og nøiaktig studert ved de omtalte impregnasjonsmetoder, som var utarbeidet av Cajal og hans elever. Disse metoder anvendes nu på gliomene, og Bailey og Cushing fant så at en eller annen av de omtalte celler dominerte svulstvevet. Etter denne celleform blev så svulsten døpt. Bailey og Cushing opstillet oprinnelig 14 gliomformer. Antallet er senere blitt noget redusert. Det skal ikke forbause at de i sin iver gikk for vidt. Bailey oprettholder i sin siste klassifisering 10 gliomformer. Jeg skal nevne navnene:

Astrocytom, ependymom, astroblastom, spongioblastoma unipolare, oligodendrogliom, medullablastom, pinealom, medulloepiteliom, glioblastom multiforme, papillom. Denne inndeling hviler altså på den kjensgjerning at gliomene er tilbøielige til å reprodusere visse embryonale celleformer som eksisterer under nervesystemets utvikling. 